\title{
Feeding habits of the bluemouth, Helicolenus dactylopterus dactylopterus (Delaroche, 1809) (Pisces: Sebastidae) in the Portuguese coast
}

\author{
Ana Neves $\cdot$ Vera Sequeira $\cdot$ Rafaela Barros Paiva \\ Ana Rita Vieira $\cdot$ Leonel Serrano Gordo
}

Received: 27 December 2010/Revised: 16 June 2011/ Accepted: 20 June 2011/Published online: 7 July 2011

(C) Springer-Verlag and AWI 2011

\begin{abstract}
In order to investigate the feeding habits of Helicolenus dactylopterus dactylopterus along the continental Portuguese coast, a total of 619 individuals were sampled of which $60 \%$ contained food in their stomach and $35 \%$ had more than one prey item. Among the 81 prey items that were identified in the stomachs, benthic and benthopelagic prey prevail on this species diet. Acantephyra sp, Pasiphaea sp, mysidacea, and teleostei n.i. were the prey with the higher percent index of relative importance (\%IRI) value. Three length groups $(5-20 \mathrm{~cm}$, 21-27 cm, and $28-48 \mathrm{~cm}$ ) were defined through cluster analysis of the mean abundance of prey items. A permutational MANOVA detected significant differences in the diet and stomach fullness index for TLG, season, and maturation stage. Smaller fishes had a generalized diet, feeding mainly on mysidacea changing their diet above $20 \mathrm{~cm} \mathrm{TL}$, where a major consumption of natantia was found. The larger individuals, $>28 \mathrm{~cm} \mathrm{TL}$, present a less generalized diet with pisces as dominant prey group. Seasonally, natantia and pisces were the principal prey groups during spring and winter, respectively, while mysidacea and other crustaceans were predominant during the rest of the year. Mysidacea were also the main prey group for immature individuals while natantia and pisces were the principal prey groups to the other maturity stages. The
\end{abstract}

Communicated by Arne Malzahn.

A. Neves $(\varangle) \cdot$ V. Sequeira $\cdot$ R. B. Paiva ·

A. R. Vieira - L. S. Gordo

Departamento de Biologia Animal e Centro de Oceanografia,

Faculdade de Ciências da Universidade de Lisboa, Bloco C2,

Campo Grande, 1749-016 Lisbon, Portugal

e-mail: ananeves73@gmail.com results of this study indicate that $H$. $d$. dactylopterus has a diverse diet focused on small crustaceans such as misyds and as specimens grow shrimps and fishes become more consumed, with larger specimens having a more specialized diet. The different nutritional needs during spawning season also seemed to influence the feeding habits of $H$. $d$. dactylopterus.

Keywords Helicolenus dactylopterus · Feeding habits · Portuguese coast · Diet

\section{Introduction}

Studies of feeding habits and diet are fundamental to understand many aspects of the biology, ecology, physiology, and behavior of fish (Gonçalves and Erzini 1998), particularly those involving the upper trophic level species are especially important due to their recent global declines and the potential for associated ecosystem-level effects on species composition and diversity (Pauly et al. 1998). Stomach content analysis is the most widely used method for studying the diet of fish and determine the role of a species in the food chain (Hyslop 1980).

Feeding studies of deep-sea species pose several problems. The most common include sample size, the eversion of the stomach, due to the upraise from great depths, and the large number of empty stomachs common for large predators. Also, the absence of data on prey availability and competitive interactions makes it difficult to classify the deep-sea fishes as generalized or specialized predators (Gartner et al. 1997). The study of diets of deepwater species, however, is an important tool for improving the characterization of these faunal communities (Neves et al. 2007). 
Table 1 Scale adopted for Helicolenus dactylopterus dactylopterus maturity stage assignments

\begin{tabular}{|c|c|c|}
\hline Maturity stages & Females & Males \\
\hline Immature & Ovaries small and translucent; without visible oocytes & Testes small, thin, and translucent \\
\hline Development & $\begin{array}{l}\text { Ovaries are larger, opaque, consistent, with rose or orange color; } \\
\text { visible oocytes }\end{array}$ & $\begin{array}{l}\text { Testes larger, flattened dorsoventrally, consistent, } \\
\text { and whitish in color }\end{array}$ \\
\hline Spawning & $\begin{array}{l}\text { Ovaries are larger and well vascularized, orange color, the hydrated } \\
\text { oocytes are well visible, when present, the gelatinous matrix consists } \\
\text { in a translucent and thick mass with small punctuations (oocytes and } \\
\text { embryos) }\end{array}$ & $\begin{array}{l}\text { Testes are whitish in color, full of sperm that runs } \\
\text { when abdomen is pressed }\end{array}$ \\
\hline Post-Spawning & $\begin{array}{l}\text { Ovaries with size similar to stages II/III, opaque, flaccid, with some } \\
\text { vascularization; residual oocytes and gelatinous matrix remainders } \\
\text { are visible }\end{array}$ & $\begin{array}{l}\text { Testes are flaccid, smaller, with bloody aspect. Can } \\
\text { present some residual sperm }\end{array}$ \\
\hline
\end{tabular}

The bluemouth, Helicolenus dactylopterus dactylopterus is a benthic deepwater scorpionfish found typically at depths of 200-1000 m. It occurs in the western and eastern Atlantic, and in the latter, it is widespread from Norway to South Africa and around the Azores, Madeira, the Canary Islands (Hureau and Litvinenko 1986), and in the Mediterranean Sea. In the North Sea, it is found in water shallower than its typical depth range (Heessen et al. 1996). This species is known to be associated with submarine mountains in the vicinity of deep canyons (Figueiredo et al. 1995) that suggest a rather sedentary existence (Uiblein et al. 2003). In Portuguese waters, $H$. $d$. dactylopterus is the most important commercial scorpaeniform, with a mean of more than $200 \mathrm{t}^{*}$ year ${ }^{-1}$ landed in the past decade (DGPA 2010).

Nevertheless, very little information is available on the feeding habits of this important commercial species. Data are only available from Mediterranean waters (Froglia 1976; Sartor et al. 1993; Nouar and Maurin 2000; Consoli et al. 2010) and Namibia (Macpherson 1985), and no information for the NE Atlantic has ever been published. This study intends to present new data that will allow a better understanding and quantification of the predator-prey relationships in a still poorly known deepwater environment. Specifically, these data will provide a detailed diet composition of $H$. $d$. dactylopterus in the Portuguese continental slope focusing on differences in the feeding habits according to length, season, sex, and maturation stage.

\section{Materials and methods}

Specimens of $H$. $d$. dactylopterus were obtained from commercial landings in Peniche, the most important port in mainland Portugal. The sampling period was February 2006 to March 2008 using both longline (horse mackerel, sardine, and Spanish mackerel as baits) and bottom trawl operating in the center region of Portugal $\left(38^{\circ} 25^{\prime} \mathrm{N}-39^{\circ} 45^{\prime} \mathrm{N}\right.$, $09^{\circ} 25^{\prime} \mathrm{W}-10^{\circ} 05^{\prime} \mathrm{W}$ ) (Fig. 1). Supplementary samples from the same region, at depths ranging from 137 to $742 \mathrm{~m}$, were obtained from bottom trawl research surveys conducted by the Portuguese Fisheries Institute (IPIMAR) during October 2005, March, April, June, and October 2006.

Total length (TL to the nearest $0.1 \mathrm{~cm}$ ), eviscerated weight (EW to the nearest $0.1 \mathrm{~g}$ ), sex, and maturity stage (Table 1) were recorded for each fish. The stomachs were removed and frozen for later analysis.

The food items in the stomach contents were identified to the lowest taxonomic level possible counted and weighed (wet weight to the nearest $0.0001 \mathrm{~g}$ ). Prey with a low level of digestions and that might have been used as bait was excluded from the analysis.

\section{Diet composition}

Prey relative importance was quantified by estimating dietary indexes (Hyslop 1980, Cortés 1997) by prey item and prey items aggregated by major taxonomic groups:

(i) frequency of occurrence

$$
\left(\% O=\frac{\text { number of stomachs with prey item } i}{\text { number of non-empty stomachs }} \times 100\right) \text {; }
$$

(ii) percentage by number

$$
\% N=\frac{\text { number of prey item } i \text { in all stomachs }}{\text { total number of food items in all stomachs }} \times 100 \text { ); }
$$

(iii) percentage by weight

$$
\left(\% W=\frac{\text { total weight of prey item } i \text { in all stomachs }}{\text { total weight of stomach contents }} \times 100\right) \text {; }
$$

(iv) percent index of relative importance

$$
\% \text { IRI }=\left[\frac{\% O \times(\% N+\% W)}{\sum(\% O \times(\% N+\% W))}\right] \times 100 ;
$$

The vacuity index (VI) was estimated as the percentage of empty stomachs in the sample (Ellis et al. 1996).

Prey curve

In order to determine whether an adequate number of bluemouth had been collected to describe the diet precisely, a cumulative prey curve was constructed (Gelsleichter et al. 1999). The order in which stomachs were analyzed was 
randomized 20 times and the mean number of new prey species found consecutively in the stomachs plotted against the number of stomachs analyzed (Ferry et al. 1997). The presence of an asymptotic relationship indicates that a sufficient number of samples had been analyzed. The method developed by Bizzarro et al. (2007) for quantitative measures of sample size sufficiency was used to determine whether the cumulative prey curves reached an asymptote; the slope of the line generated from the curve's four last points was compared through a Student's $t$ test to a line of zero slope (horizontal asymptote). If slopes were not significantly different $(P>0.05)$, it would indicate that the curve reached an asymptote. The mean coefficient of variation of the four last points was additionally calculated to provide a standard measure of precision.

\section{Group dietary}

To evaluate the degree of feeding intensity of each individual, the stomach fullness index $(\mathrm{SFI})$ was used. SFI $=\frac{\mathrm{SCW}}{\mathrm{EW}} \times 100$ where SCW is the stomach content weight (Hyslop 1980).

For the subsequent analyses, prey items were merged into major taxonomic groups (polychaetes-POL, mysidacea-MYS, natantia-NAT, anomura-ANO, brachyurans-BRA, other crustaceans-OCR, molluscs-MOL, echinoderms-ECH, and pisces-PIS) to avoid problems with low expected frequencies.

To investigate diet differences between fish size classes, a cluster analysis (Ward's method, Manhattan distance) for the mean number of each prey item by predator's $1-\mathrm{cm}$ length class was conducted. The results revealed three length groups, henceforward referred to as TLGs.

A permutational MANOVA (PERMANOVA) (Anderson 2005) based on the Bray-Curtis distance measure was used to test whether there were statistical differences for the abundance of prey (diet) and stomach fullness index by TLG, season, sex, and maturity stage. The discriminating prey for each significant factor were determined using the similarity percentage_-SIMPER (Clarke 1993).

Feeding strategy

Feeding strategy by life stage was examined through graphical representation as proposed by Cortés (1997) and using the most representative prey items aggregated by the major taxonomic groups mention above.

\section{Results}

During the study period, 624 individuals ( 347 females, 273 males and 4 undetermined) of $H$. d. dactylopterus ranging between 5.2 and $46.9 \mathrm{~cm}$ TL were sampled (Fig. 2). Only

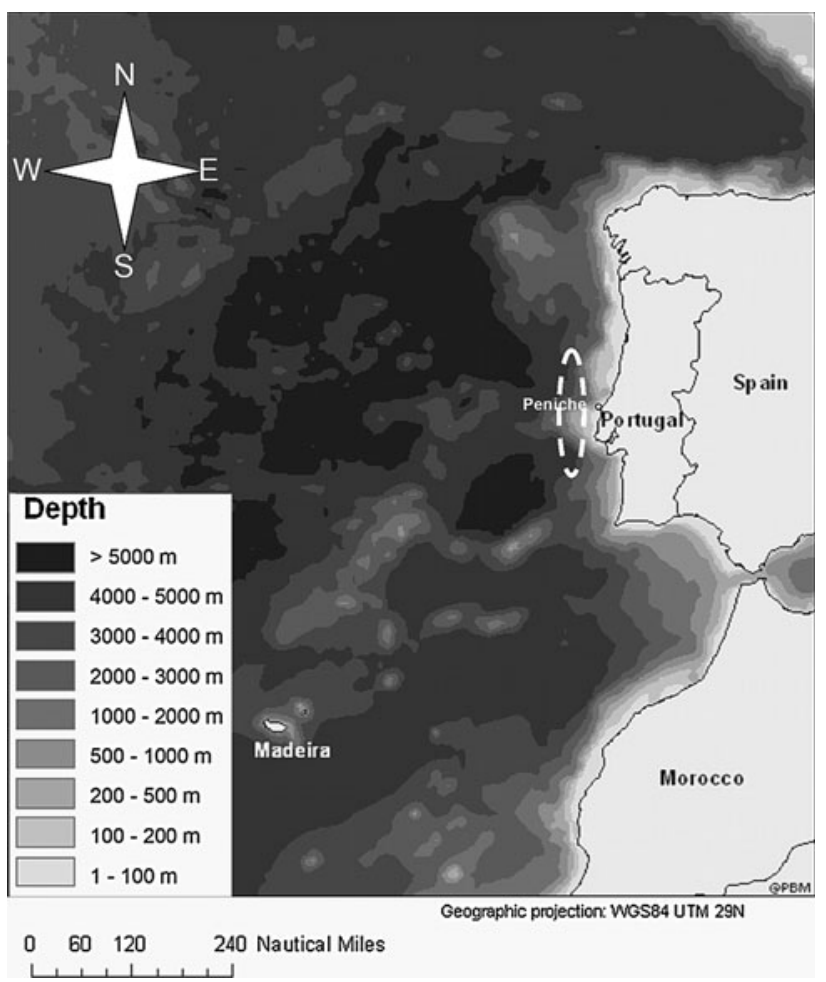

Fig. 1 Geographical location of the sampling areas in the Portuguese coast (dashed ellipse)

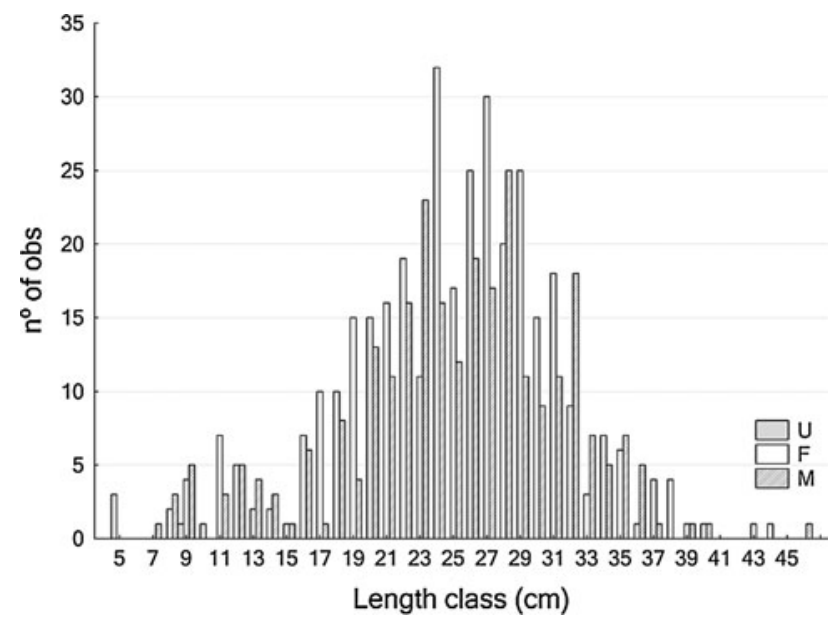

Fig. 2 Length frequency distribution (1 $\mathrm{cm}$ classes) for undetermined, female and male Helicolenus dactylopterus dactylopterus individuals sampled

78 of the analyzed individuals were caught by longline, being 268 caught by bottom trawl commercial fleet, and 278 sampled by bottom trawl research surveys.

Diet composition

A total of 81 prey items were identified in the stomachs of H. d. dactylopterus, but only 14 occurred in more than $5 \%$ 
of the stomachs. Benthic and benthopelagic prey prevailed on this species diet.

This species showed a high vacuity index of $40 \%$, while $35 \%$ of the analyzed stomachs had more than one prey item.

Natantia was the main prey group with the highest values for all indices with the exception of $\% O$. Within this group, Pasiphaea sp and Acanthephyra sp were the most consumed prey. Mysidacea and teleostei n.i. were also important prey in H.d. dactylopetrus diet, both with a high $\% O$. Two groups, natantia and pisces, accounted for almost $90 \%$ of the total prey weight (Table 2).

Prey curve

The cumulative prey curve confirmed that the number of collected bluemouth to describe the diet was adequate (Fig. 3). The curve generated $\left(n_{\min }=599\right)$ displayed no variability at endpoints $(\mathrm{CV}=0 \%)$.

\section{Group dietary}

The cluster analysis (Fig. 4) enabled to identify three groups: TLG1, 5-20 cm $(n=138)$, TLG2, $21-27 \mathrm{~cm}$ $(n=268)$, and TLG3, $>28 \mathrm{~cm}(n=213)$. Sex and maturation stage distribution by TLG is given in Table 3 . Females were always more abundant than males, and only in TLG3, this ratio did not significantly differ from 1:1 $\left(\chi^{2}=1.53, P=0.2164\right)$. The immature individuals were dominant in TLG1 being absent from the other groups, with exception of 3 males in TLG2. The other groups were characterized mainly by spawning females and developing and spawning males.

Diet composition showed significant differences among TLG, seasons, and maturation stages (Table 4). According to fish length (Fig. 5a), mysidacea, other crustacea and echinoderms were the most important prey groups for TLG1 and accounted for $86 \%$ of the similarity within this group. Natantia and pisces were the predominant prey groups for TLG2 and TLG3 accounting for 50 and $80 \%$ of the similarity within each group, respectively.

Seasonally, natantia and pisces were the principal prey groups during spring and winter, respectively, and accounted for 85 and $86 \%$ of similarity within spring and winter groups, respectively. Mysidacea and other crustaceans were predominant during the rest of the year (Fig. 5b), accounting mysidacea, pisces, and other crustaceans for $84 \%$ of similarity within autumn group while other crustaceans and echinoderms represented $80 \%$ within the summer group.

Immature individuals fed mainly on mysidacea, while the developing and mature specimens nourished on natantia and pisces and post-spawning fish on pisces and
Table 2 Diet composition of Helicolenus dactylopterus dactylopterus expressed as frequency of occurrence $(\% O)$, percentage by number $(\% N)$, percentage by weight $(\% W)$, and percent index of relative importance (\%IRI)

\begin{tabular}{|c|c|c|c|c|}
\hline & $\% N$ & $\% O$ & $\% W$ & $\%$ IRI \\
\hline Annelida & 1.06 & 7.20 & 0.22 & 0.20 \\
\hline Polychaeta n.i. ${ }^{\text {b }}$ & 0.78 & 5.20 & 0.21 & 0.19 \\
\hline Ampharetidae $^{\mathrm{b}}$ & 0.11 & 0.80 & 0.00 & 0.00 \\
\hline Phyllodocidae $^{\mathrm{b}}$ & 0.17 & 1.20 & 0.00 & 0.01 \\
\hline Non-decapod crustacea & 30.38 & 94.40 & 1.74 & 20.70 \\
\hline Crustacea n.i. ${ }^{\text {bp }}$ & 1.34 & 9.20 & 0.07 & 0.48 \\
\hline Copepoda $^{\mathrm{p}}$ & 0.17 & 1.20 & 0.00 & 0.01 \\
\hline Mysidacea $^{\text {bp }}$ & 12.02 & 25.20 & 0.11 & 11.42 \\
\hline Siriella $\mathrm{sp}^{\mathrm{bp}}$ & 0.06 & 0.40 & 0.00 & 0.00 \\
\hline Gnasthophasia zoea ${ }^{\mathrm{bp}}$ & 0.50 & 0.40 & 0.02 & 0.01 \\
\hline Isopoda $^{\text {bp }}$ & 0.33 & 2.00 & 0.03 & 0.03 \\
\hline Cirolanidae $^{\text {bp }}$ & 1.11 & 4.00 & 0.04 & 0.17 \\
\hline Cirolana $\mathrm{sp}^{\mathrm{bp}}$ & 5.40 & 10.80 & 0.23 & 2.27 \\
\hline Eurydice $\mathrm{sp}^{\mathrm{bp}}$ & 0.72 & 3.20 & 0.09 & 0.10 \\
\hline Munnidae $^{\text {bp }}$ & 0.11 & 0.40 & 0.00 & 0.00 \\
\hline Amphipoda $^{\text {bp }}$ & 4.06 & 17.20 & 0.08 & 2.66 \\
\hline Lysianassidae $^{\text {bp }}$ & 0.17 & 1.20 & 0.00 & 0.01 \\
\hline Pardaliscidae $\mathrm{bp}^{\mathrm{bp}}$ & 0.11 & 0.80 & 0.01 & 0.00 \\
\hline Caprellidae $^{\text {bp }}$ & 0.06 & 0.40 & 0.00 & 0.00 \\
\hline Euphausiacea $^{\mathrm{p}}$ & 4.23 & 18.00 & 1.05 & 3.55 \\
\hline Natantia & 47.91 & 63.60 & 46.31 & 66.12 \\
\hline Natantia n.i. ${ }^{\text {bp }}$ & 8.63 & 17.20 & 7.21 & 9.15 \\
\hline Pasiphaea $\mathrm{sp}^{\mathrm{p}}$ & 11.02 & 19.60 & 12.99 & 17.56 \\
\hline Pasiphaea sivado ${ }^{\mathrm{p}}$ & 0.33 & 0.40 & 0.39 & 0.01 \\
\hline Oplophorus $\mathrm{sp}^{\mathrm{bp}}$ & 0.39 & 2.00 & 0.17 & 0.04 \\
\hline Acanthephyra $\mathrm{sp}^{\mathrm{bp}}$ & 26.71 & 20.40 & 24.90 & 39.31 \\
\hline Acanthephyra pelagica ${ }^{\mathrm{p}}$ & 0.39 & 0.80 & 0.25 & 0.02 \\
\hline Alpheus sp ${ }^{\mathrm{b}}$ & 0.11 & 0.80 & 0.03 & 0.00 \\
\hline Alpheus glaber $^{\mathrm{b}}$ & 0.28 & 2.00 & 0.08 & 0.03 \\
\hline Polycheles $\mathrm{sp}^{\mathrm{b}}$ & 0.06 & 0.40 & 0.29 & 0.01 \\
\hline Anomura & 1.00 & 7.20 & 1.57 & 0.25 \\
\hline Anomura n.i. ${ }^{\mathrm{b}}$ & 0.11 & 0.80 & 0.05 & 0.00 \\
\hline Paguridae $^{\mathrm{b}}$ & 0.50 & 3.60 & 0.74 & 0.17 \\
\hline Munida $\mathrm{sp}^{\mathrm{b}}$ & 0.28 & 2.00 & 0.77 & 0.08 \\
\hline Galathea $\mathrm{sp}^{\mathrm{b}}$ & 0.11 & 0.80 & 0.01 & 0.00 \\
\hline Brachyura & 2.84 & 20.00 & 3.44 & 1.09 \\
\hline Brachyura n.i. & 0.45 & 3.20 & 0.28 & 0.09 \\
\hline Ebalia $\mathrm{sp}^{\mathrm{b}}$ & 0.17 & 1.20 & 0.01 & 0.01 \\
\hline Atelecyclus rotundatus ${ }^{\mathrm{b}}$ & 0.22 & 1.60 & 0.31 & 0.03 \\
\hline Portunidae $^{\mathrm{b}}$ & 0.11 & 0.80 & 0.37 & 0.01 \\
\hline Polybius henslowii ${ }^{\mathrm{bp}}$ & 0.06 & 0.40 & 0.98 & 0.02 \\
\hline Liocarcinus $\mathrm{sp}^{\mathrm{b}}$ & 0.11 & 0.80 & 0.03 & 0.00 \\
\hline Pilumnus $\mathrm{sp}^{\mathrm{b}}$ & 0.06 & 0.40 & 0.10 & 0.00 \\
\hline Goneplax rhomboides ${ }^{\mathrm{b}}$ & 1.34 & 9.20 & 1.33 & 0.91 \\
\hline Maja goltziana ${ }^{b}$ & 0.06 & 0.40 & 0.00 & 0.00 \\
\hline Macropodia $\mathrm{sp}^{\mathrm{b}}$ & 0.11 & 0.80 & 0.01 & 0.00 \\
\hline
\end{tabular}


Table 2 continued

\begin{tabular}{|c|c|c|c|c|}
\hline & $\% N$ & $\% O$ & $\% W$ & $\%$ IRI \\
\hline Inachus $\mathrm{sp}^{\mathrm{b}}$ & 0.06 & 0.40 & 0.00 & 0.00 \\
\hline Ergasticus clouei $^{\mathrm{b}}$ & 0.11 & 0.80 & 0.02 & 0.00 \\
\hline Mollusca & 1.11 & 7.20 & 1.50 & 0.17 \\
\hline Eulimidae $^{\mathrm{b}}$ & 0.45 & 2.40 & 0.07 & 0.05 \\
\hline Buccinidae $^{\mathrm{b}}$ & 0.11 & 0.80 & 0.27 & 0.01 \\
\hline Cephalopoda n.i. ${ }^{\text {bp }}$ & 0.28 & 2.00 & 0.62 & 0.07 \\
\hline Sepietta oweniana ${ }^{\mathrm{p}}$ & 0.22 & 1.60 & 0.46 & 0.04 \\
\hline Octopodidae $^{\mathrm{b}}$ & 0.06 & 0.40 & 0.08 & 0.00 \\
\hline Echinodermata & 8.90 & 31.60 & 1.87 & 1.96 \\
\hline Echinodermata n.i. ${ }^{\mathrm{b}}$ & 0.11 & 0.80 & 0.00 & 0.00 \\
\hline Ophiuroidea $^{\mathrm{b}}$ & 1.11 & 7.60 & 0.08 & 0.34 \\
\hline Ophiura $\mathrm{sp}^{\mathrm{b}}$ & 1.34 & 5.20 & 0.27 & 0.31 \\
\hline Ophiura ophiura ${ }^{\mathrm{b}}$ & 1.11 & 4.40 & 0.03 & 0.19 \\
\hline Ophiura albida ${ }^{b}$ & 0.78 & 2.00 & 0.18 & 0.07 \\
\hline Amphiura $\mathrm{sp}^{\mathrm{b}}$ & 0.06 & 0.40 & 0.03 & 0.00 \\
\hline Amphiura filiformis ${ }^{b}$ & 0.11 & 0.80 & 0.02 & 0.00 \\
\hline Ophiothrix $\mathrm{sp}^{\mathrm{b}}$ & 0.61 & 3.20 & 0.66 & 0.15 \\
\hline Ophiothrix fragilis $^{b}$ & 0.17 & 1.20 & 0.21 & 0.02 \\
\hline Ophiocomina nigra $^{b}$ & 3.51 & 6.00 & 0.39 & 0.87 \\
\hline Pisces & 6.79 & 47.60 & 43.34 & 9.51 \\
\hline Teleostei n.i. ${ }^{\text {bp }}$ & 3.23 & 23.20 & 2.84 & 5.26 \\
\hline Xenodermichthys copei ${ }^{\mathrm{p}}$ & 0.06 & 0.40 & 0.17 & 0.00 \\
\hline Gonostoma elongatum $^{\mathrm{p}}$ & 0.06 & 0.40 & 2.62 & 0.04 \\
\hline Stomias boa ${ }^{\mathrm{p}}$ & 0.06 & 0.40 & 0.42 & 0.01 \\
\hline Myctophidae $^{\mathrm{p}}$ & 0.06 & 0.40 & 0.01 & 0.00 \\
\hline Notoscopelus $\mathrm{sp}^{\mathrm{p}}$ & 0.11 & 0.80 & 0.08 & 0.01 \\
\hline Coelorinchus caelorhincus ${ }^{\text {bp }}$ & 0.06 & 0.40 & 0.58 & 0.01 \\
\hline Merluccius merluccius ${ }^{\mathrm{b}}$ & 0.06 & 0.40 & 0.12 & 0.00 \\
\hline Gadiculus argenteus $^{\mathrm{p}}$ & 0.67 & 3.60 & 1.56 & 0.30 \\
\hline Micromesistius poutassou ${ }^{\mathrm{bp}}$ & 0.22 & 1.60 & 6.78 & 0.42 \\
\hline Phycis $\mathrm{sp}^{\mathrm{bp}}$ & 0.06 & 0.40 & 0.02 & 0.00 \\
\hline Phycis blennoides ${ }^{\mathrm{bp}}$ & 0.45 & 3.20 & 8.36 & 1.05 \\
\hline Capros aper ${ }^{\mathrm{b}}$ & 0.61 & 4.40 & 11.63 & 2.01 \\
\hline Mullus $\mathrm{sp}^{\mathrm{b}}$ & 0.06 & 0.40 & 1.03 & 0.02 \\
\hline Lepidopus caudatus $^{\mathrm{bp}}$ & 0.11 & 0.80 & 0.15 & 0.01 \\
\hline Scomber colias $^{\mathrm{p}}$ & 0.11 & 0.80 & 0.87 & 0.03 \\
\hline Lesueurigobius $\mathrm{sp}^{\mathrm{b}}$ & 0.17 & 1.20 & 0.48 & 0.03 \\
\hline Helicolenus dactylopterus ${ }^{\mathrm{b}}$ & 0.22 & 1.60 & 3.80 & 0.24 \\
\hline Lepidotrigla dieuzeidei ${ }^{\mathrm{b}}$ & 0.17 & 1.20 & 0.95 & 0.05 \\
\hline Scophthalmidae ${ }^{\mathrm{b}}$ & 0.11 & 0.80 & 0.50 & 0.02 \\
\hline Lepidorhombus boscii ${ }^{\mathrm{b}}$ & 0.06 & 0.40 & 0.37 & 0.01 \\
\hline Arnoglossus $\mathrm{sp}^{\mathrm{b}}$ & 0.06 & 0.40 & 0.00 & 0.00 \\
\hline Arnoglossus laterna ${ }^{\mathrm{b}}$ & 0.06 & 0.40 & 0.00 & 0.00 \\
\hline
\end{tabular}

Subtotals for higher taxonomic levels are presented in bold. Type of habitat is given for each prey ( $b$ bentonic, $b p$ bentopelagic, $p$ pelagic)

other crustaceans (Fig. 5c). The results for similarity test reported mysidacea as the main prey group for immature individuals ( $72 \%$ in females and $63.5 \%$ in males). In

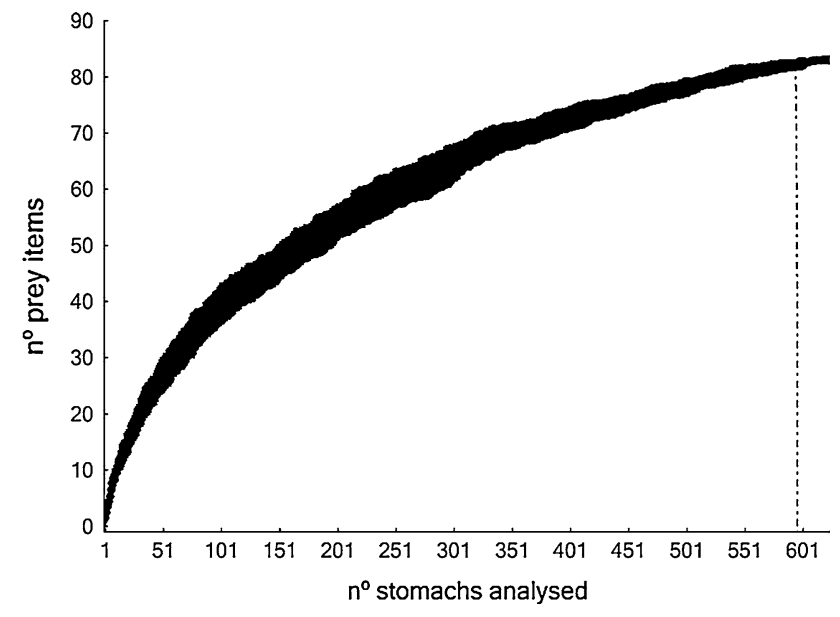

Fig. 3 Randomized cumulative prey curves for Helicolenus dactylopterus dactylopterus samples. Mean values are plotted, error bars represent \pm SE. Drop lines indicate the minimum number of samples necessary for adequate sample sizes

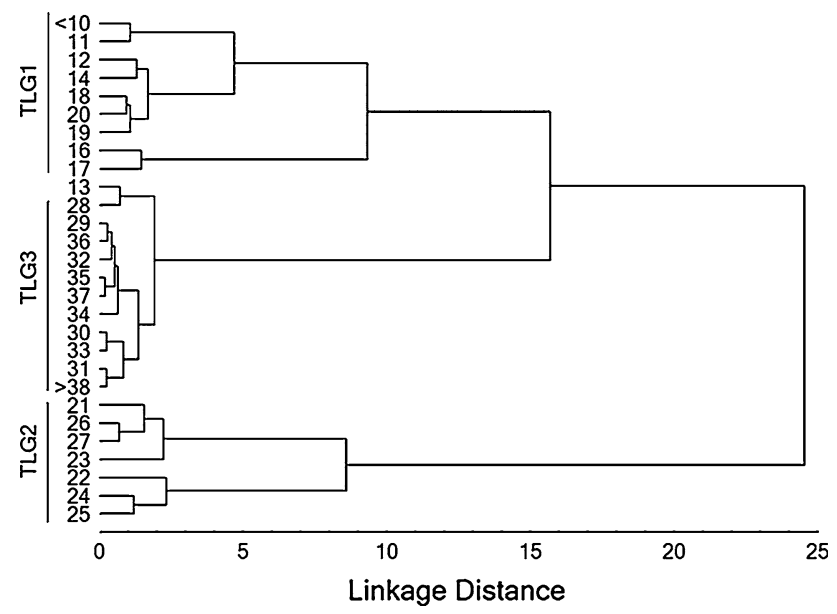

Fig. 4 Dendrogram resulting from the hierarchical cluster analysis of the mean abundance of each prey group by predator length class of $1 \mathrm{~cm}$ using Ward's method and Manhattan distances. Three major length groups (TLGs) were defined: (1) 5-20 cm, (2) $21-27 \mathrm{~cm}$, and (3) $28-48 \mathrm{~cm}$

developing females, pisces represented $77 \%$, while natantia represented $67 \%$ in males. Natantia and pisces accounted for $65 \%$ of similarity for spawning females and other crustacean, and pisces represented $79 \%$ for spawning males group. Other crustaceans (62\%) and pisces (87\%) were the major prey for post-spawning females and males, respectively.

SFI showed significant differences among TLG and seasons (Table 4). According to the individuals' length, TLG2 showed a SFI higher than the two other groups (Fig. 6a). During spring, the SFI values were much higher than those registered for the rest of the year (Fig. 6b). 
Table 3 Sex and maturation stage distribution for Helicolenus dactylopterus dactylopterus individuals by length group

\begin{tabular}{llccc}
\hline & & TLG1 & TLG2 & TLG3 \\
\hline F & Immature & 34 & & \\
& Developing & 7 & 25 & 33 \\
& Spawning & 29 & 105 & 70 \\
& Post-spawning & 11 & 21 & 12 \\
M & Immature & 39 & 3 & \\
& Developing & 2 & 64 & 37 \\
& Spawning & 10 & 43 & 37 \\
& Post-spawning & 6 & 8 & 23 \\
& F:M & $1.4: 1$ & $1.3: 1$ & $1.2: 1$ \\
\hline
\end{tabular}

Sex ratio is given in the last row

Feeding strategy

The three-dimensional graphical representation of the diet of $H . d$. dactylopterus by TLG (Fig. 7) reinforces the results presented in group dietary. Individuals from TLG1 fed mainly on mysids, while the echinoderms were a frequent prey and the natantia and pisces were significant in terms of weight.

Natantia was the dominant prey group for TLG2 although the other crustaceans also contributed significantly for the diet in terms of number, while pisces contributed essentially for the weight. Individuals from TLG3 presented the least generalist diet with pisces being the clear dominant prey group.

\section{Discussion}

Fish diet is particularly difficult to assess in generalist feeders since a large number of samples is needed to correctly guarantee the evaluation of species diet. In the present study, information was gathered using different gears and years but due to the scarcity of data from longline fishery and uneven sampling along the years, it was not possible to compare the results between gears operating in different grounds and years. $H$. $d$. dactylopterus tends to present a high number of empty stomachs, $40 \%$ in our study and reaching 50\% in several other studies (Nouar and Maurin 2000; Colloca et al. 2010; Consoli et al. 2010). This reflects the species feeding strategy which, according to Macpherson (1985), is primary a daytime predator feeding during a relative short period, after which it remains inactive and does not ingest prey until the previous prey item has been digested.

According to our results and unlike Colloca et al. (2010)'s study, two clear dietary shifts (at $20 \mathrm{~cm}$ and $28 \mathrm{~cm}$ TL) occur along $H$. d. dactylopterus life.

The first shift seems to be related to the first maturation, which occurs between 16.0 and $20.0 \mathrm{~cm}$ TL off mainland Portugal and also visible in the otolith deposition pattern (Sequeira et al. 2009). The second shift could not be directly associated with the maturity condition, since all maturation stages, with exception of immature, are well represented between the two TLGs. However, the nutritional needs during the species growth change and therefore some shifts in its diet can be noticed. Smaller individuals have a generalized diet, feeding mainly on mysidacea changing their diet above $20 \mathrm{~cm}$ TL, where a major consumption of natantia takes place. The larger individuals, above $28 \mathrm{~cm}$, present a much less generalized diet with pisces being the dominant prey group.

Rodríguez-Mendoza et al. (2011) observed changes in mouth shape and position during the growth of bluemouth, which are very likely related to ontogenetic changes in the diet of bluemouth. Mouth morphology plays an essential role in determining the type of prey consumed, and morphological variations can lead to changes in foraging/predation ability and subsequently differential exploitation of food resources (Karpouzi and Stergiou 2003).

Table 4 Statistical results for Helicolenus dactylopterus dactylopetrus diet and stomach fullness index (SFI) comparison among length groups, seasons, sex, and maturation with permutational multivariate analysis of variance

\begin{tabular}{|c|c|c|c|c|c|c|c|c|}
\hline & \multicolumn{4}{|l|}{ Diet } & \multicolumn{4}{|l|}{ SFI } \\
\hline & F. Model & $R^{2}$ & $\operatorname{Pr}(>F)$ & $d f$ & F. Model & $R^{2}$ & $\operatorname{Pr}(>F)$ & $d f$ \\
\hline Season & 23.0264 & 0.1511 & 0.0010 & 3 & 15.0211 & 0.1058 & 0.0010 & 3 \\
\hline TLG & 9.8402 & 0.0430 & 0.0010 & 2 & 5.7366 & 0.0270 & 0.0010 & 2 \\
\hline Sex:TLG & 0.3446 & 0.0015 & 0.9720 & 2 & 0.8729 & 0.0041 & 0.4995 & 2 \\
\hline Maturation stage, sex & 2.1745 & 0.0143 & 0.0050 & 3 & 0.8767 & 0.0062 & 0.5694 & 3 \\
\hline Residuals & & 0.7741 & & 354 & & 0.8384 & & 357 \\
\hline Total & & 1.0000 & & 368 & & 1.0000 & & 371 \\
\hline
\end{tabular}

Formula $=$ Diet/SFI $\sim$ Season + TLG $+S *$ TLG + MMS $* S$, permutations $=1,000)(\operatorname{Pr}(>F)$ —statistic $P$ value; $d f$ degrees of freedom $)$

Significant values are given in bold 
Fig. 5 Contribution of each major taxonomic prey group for the diet of Helicolenus dactylopterus dactylopeterus by TLG (a), season (b), and maturation group (c)
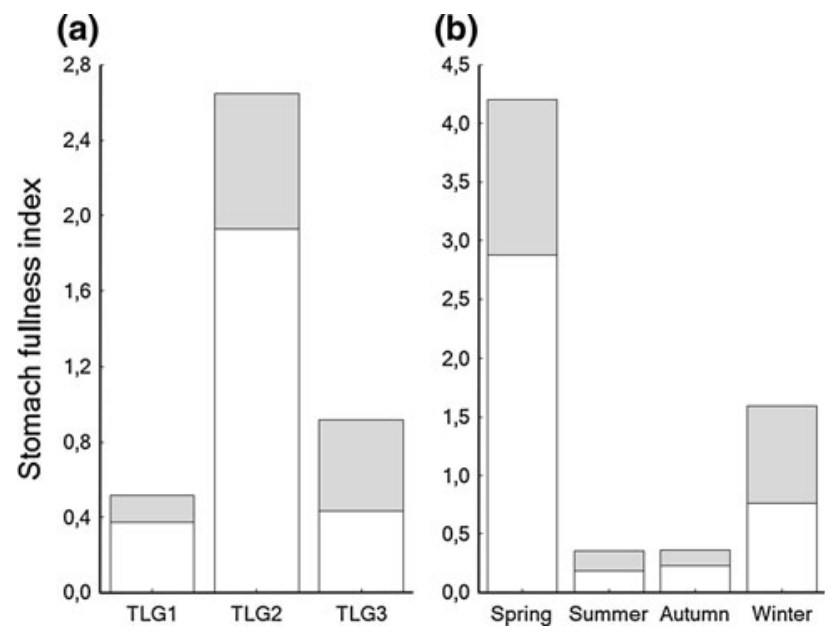

Fig. 6 Mean SFI observed by TLG (a) and season (b) for Helicolenus dactylopterus dactylopterus stomachs

Considering the feeding strategy, crustaceans were already pointed out as the preferred prey for smaller $H$. $d$. dactylopterus individuals by several authors (Nouar and Maurin 2000; Consoli et al. 2010). The former authors found that fishes are also an important prey for bluemouth individuals, but they did not observe an increase in importance in fish as prey for larger individuals. Nevertheless, these authors had only two individuals above $30 \mathrm{~cm}$. In the Consoli et al. (2010) study, fishes were a prey group with low importance in the species diet, but $87 \%$ of individuals in this study had less than $13.7 \mathrm{~cm}$ and few individuals were caught below $400 \mathrm{~m}$ depth. It is known

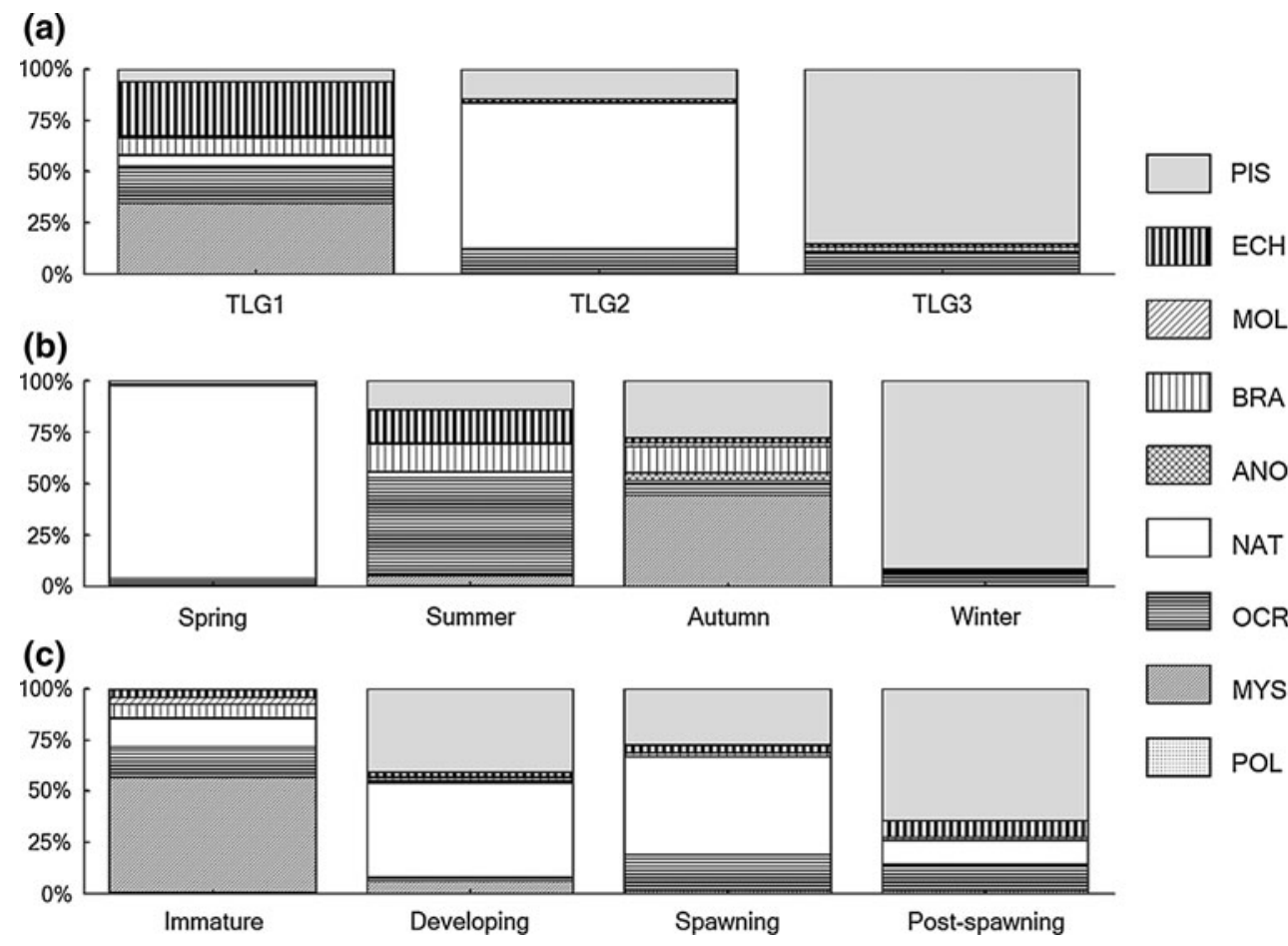

that larger $H$. d. dactylopterus are found deeper (Ribas et al. 2006), and in the Portuguese continental slope, the larger individuals can be found at 500-750 m depth (Cardador and Pestana 1995).

Other species closely related to bluemouth show a similar pattern in their food habits with crustaceans as an important portion of individuals' diet and with a notable increase in the consumption of fish with increasing predator size. Such is the case of the redfish Sebastes marinus in Icelandic waters (Jaworski and Ragnarsson 2006) and $S$. caurinus and $S$. maliger from Saanich Inlet, Canada (Murie 1995).

Several authors, as reported by Nouar and Maurin (2000), have already noticed the dominance of benthic and benthopelagic prey in bluemouth diet. This suggests that it preys mainly near the bottom with no evidence of feeding migrations in the water column. Actually, Uiblein et al. (2003) observed, based on video sequences on the Bay of Biscay, that this species is characterized as a typical sitand-wait predator that likely attacks its prey at short distances and close to the bottom. Nevertheless, the species has a pelagic larvae and juveline phase (Hureau and Litvinenko 1986). The presence of typically pelagic species in our study (e.g., Lepidopus caudatus) may also suggest an active predation in the water column or the ingestion of dead specimens sank to the bottom.

During our study, no significant differences were noticed between male and females' diet. Nouar and Maurin (2000) also found that males and females fed on the same prey with some differences among the abundance of certain 
Fig. 7 Three-dimensional representation of the feeding strategy of Helicolenus dactylopterus dactylopterus by TLG ( $P O L$ polychaetes, MYS mysidacea, NAT natantia, ANO anomura, $B R A$ brachyurans, $O C R$ other crustaceans, $M O L$ molluscs, $E C H$ echinoderms, and $P I S$ pisces)
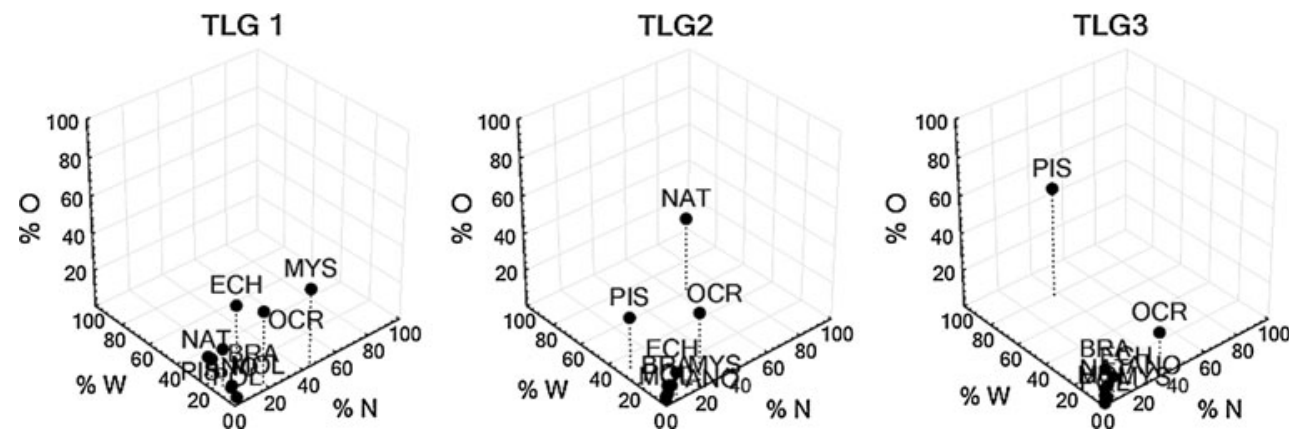

groups. However, and regarding females, higher values of SFI were registered during winter and spring, the period that corresponds to the spawning season of the species (Sequeira et al. 2011) and when a greater energetic effort is necessary.

The results of this study indicate that $H$. d. dactylopterus have a diverse diet focused on small crustaceans such as misyds and as specimens grow shrimps and fishes become more consumed, with larger specimens having a more specialized diet. The different nutritional needs during spawning season also seams to influence the feeding habits of $H$. d. dactylopterus.

The improvement of the understanding and quantification of the predator-prey relationships in a still poorly known deepwater environment and this information on the biological interactions can, in the future, be incorporated in trophic/ecosystem-based modeling essential for the correct management of the ecosystems.

Acknowledgments The authors are grateful to Prof. Carlos Assis for the identification of fish otoliths. We also would like to thank the three referees for their comments that largely improve the manuscript and Dr. Alberto Pereira for the English revision. This study was partially financed by the Fundação para a Ciência e Tecnologia (FCT), through the grant attributed to V. Sequeira (Grant SFRH/ BDD/22746/2005).

\section{References}

Anderson MJ (2005) PERMANOVA: a FORTRAN computer program for permutational multivariate analysis of variance. Department of Statistics, University of Auckland, New Zealand

Bizzarro JJ, Robinson HJ, Rinewalt CS, Ebert DA (2007) Comparative feeding ecology of four sympatric skate species off central California, USA. Environ Biol Fish 80:197-220

Cardador F, Pestana G (1995) Abundance and distribution pattern of Rock fish (Helicolenus dactylopterus) in the Portuguese continental waters (ICES, Div.IXa). ICES CM 1995/G:19

Clarke KR (1993) Non-parametric multivariate analyses of changes in community structure. Aust J Ecol 18:117-143

Colloca F, Carpentieri P, Balestri E, Arizzone G (2010) Food resources portioning in a Mediterranean demersal fish assemblage: the effect of body size and niche width. Mar Biol 157:565-574

Consoli P, Battaglia P, Castriota L, Esposito V, Romeo T, Andaloro F (2010) Age, growth and feeding habits of the bluemouth rockfish, Helicolenus dactylopterus dactylopterus (Delaroche 1809) in the central Mediterranean (southern Tyrrhenian Sea). J Appl Ichthyol 26:583-591

Cortés E (1997) A critical review of methods of studying fish feeding based on analysis of stomach contents: application to elasmobranch fishes. Can J Fish Aquat Sci 54:726-738

DGPA (2010) Recursos da Pesca-Série Estatística. DGPA, Lisboa

Ellis JR, Pawson MG, Shackley SE (1996) The comparative feeding ecology of six species of shark and four species of ray (elasmobranchii) in the north-east Atlantic. J Mar Biol Assoc UK 76:89-106

Ferry LA, Clark SL, Cailliet GM (1997) Food habits of spotted sand bass (Paralabrax maculatofasciatus, Serranidae) from Bahia de Los Angeles, Baja California. Bull South Calif Acad Sci 96:1-21

Figueiredo MJ, Figueiredo I, Moura O (1995) Distribution, abundance and size composition of blackbelly rosefish (Helicolenus dactylopterus) and Mediterranean redfish (Hoplostethus mediterraneus) on the slope of the Portuguese south and southern west coasts. ICES CM 1995/G:10

Froglia C (1976) Observations on the feeding of Helicolenus dactylopterus (Delaroche) (Pisces: Scorpaenidae) in the Mediterranean sea. Rapp Comm Int Expl Scien Médit 23:47-48

Gartner JV Jr, Crabtree RE, Sulak KJ (1997) Feeding at depth. In: Randall D, Farrell AP (eds) Deep-sea fishes. Academic Press, San Diego, pp 115-193

Gelsleichter J, Musick JA, Nichols S (1999) Food habits of the smooth dogfish, Mustelus canis, dusky shark, Carcharhinus obscurus, atlantic sharpnose shark, Rhizoprionodon terraenovae, and the sand tiger, Carcharias taurus, from the northwest Atlantic ocean. Environ Biol Fish 54:205-217

Gonçalves JM, Erzini K (1998) Feeding habits of the two-banded sea bream (Diplodus vulgaris) and the black sea bream (Spondyliosoma cantharus) (Sparidae) from the south-west coast of Portugal. Cybium 22:245-254

Heessen H, Hislop J, Boon TW (1996) An invasion of the North Sea by blue-mouth, Helicolenus dactylopterus (Pisces, Scorpaenidae). ICES J Mar Sci 53:874-877

Hureau JC, Litvinenko NI (1986) Scorpaenidae. In: Whitehead PJP, Bauchot M-L, Hureau J-C, Nielsen J, Tortonese E (eds) Fishes of the North-eastern Atlantic and the Mediterranean. FAO, Rome, pp 1211-1229

Hyslop E (1980) Stomach content analysis-a review of methods and their application. J Fish Biol 17:411-429

Jaworski A, Ragnarsson S (2006) Feeding habits of demersal fish in Icelandic waters: a multivariate approach. ICES J Mar Sci 63:1682-1694

Karpouzi VS, Stergiou KI (2003) The relationships between mouth size and shape and body length for 18 species of marine fishes and their trophic implications. J Fish Biol 62:1353-1365

Macpherson E (1985) Daily ration and feeding periodicity of some fishes off the coast of Namibia. Mar Ecol Prog Ser 26:253260 
Murie DJ (1995) Comparative feeding ecology of two sympatric rockfish congeners, Sebastes caurinus (copper rockfish) and S. maliger (quillback rockfish). Mar Biol 124:341-353

Neves A, Figueiredo I, Moura T, Assis C, Gordo LS (2007) Diet and feeding strategy of Galeus melastomus in the continental slope off southern Portugal. Vie Milieu 57:165-169

Nouar A, Maurin C (2000) Régime alimentaire de Helicolenus dactylopterus dactylopterus (Pisces: Scorpaenidae) des fonds chalutables des cotes algériennes. Cah Biol Mar 41:313-320

Pauly D, Trites AW, Capuli E, Christensen V (1998) Diet composition and trophic levels of marine mammals. ICES J Mar Sci 55:467-481

Ribas D, Muñoz M, Casadevall M, Gil de Sola L (2006) How does the northern Mediterranean population of Helicolenus dactylopterus dactylopterus resist fishing pressure? Fish Res 79:285-293

Rodríguez-Mendoza R, Muñoz M, Saborido-Rey F (2011) Ontogenetic allometry of the bluemouth, Helicolenus dactylopterus dactylopterus (Teleostei: Scorpaenidae), in the Northeast
Atlantic and Mediterranean based on geometric morphometrics. Hydrobiologia. doi:10.1007/s10750-011-0675-7

Sartor P, Biagi F, Mori M (1993) Feeding habits and trophic relationships in Phycis blennoides (Bruenich), Lepidorhombus boscii (Risso) and Helicolenus dactylopterus (Delaroche, 1809) (Pisces, Osteichthyes) in the northern Tyrrhenian Sea. Biol Mar Medit 1:161-166

Sequeira V, Neves A, Vieira AR, Figueiredo I, Gordo LS (2009) Age and growth of bluemouth, Helicolenus dactylopterus, from the Portuguese continental slope. ICES J Mar Sci 66:524-531

Sequeira V, Vila S, Neves A, Rifes P, Nunes ML, Vieira AR, Paiva RB, Muñoz M, Gordo LS (2011) The gelatinous matrix of Helicolenus dactylopterus (Delaroche, 1809) in the context of its reproductive strategy. Mar Biol Res 7:478-487. doi:10.1080/ 17451000.2010 .528769

Uiblein F, Lorance O, Latrouite D (2003) Behaviour and habitat utilisation of seven demersal fish species on the Bay of Biscay continental slope, NE Atlantic. Mar Ecol Progr Ser 257:223-232 